\title{
Outbreak and Insecticide Susceptibility of Pod Feeding-larvae on Cocoa in Ghana
}

\author{
Silas Wintuma Avicor*, Richard Adu-Acheampong and Godfred Kweku Awudzi \\ Entomology Division, Cocoa Research Institute of Ghana, P.O. Box 8, New Tafo-Akim, Ghana
}

\begin{abstract}
Cocoa is an important foreign exchange earner and a major source of income for several households in Ghana. In 2018, a larval outbreak on cocoa pods was reported in Ghana. Although the origin is unknown, it was perceived to be a secondary pest outbreak. In this study, a survey was conducted in the outbreak areas to identify and determine the occurrence of the pest and its susceptibility to a commonly used insecticide. Field and laboratory studies were conducted to identify the pest, determine the level of infestation, insecticide susceptibility, and field management. The outbreak was mainly caused by larvae of Anomis leona ( $\sim 96 \%$ infestation of cocoa trees in some communities) with extensive feeding damage (chewing channels/tunnels) on the pericarp of pods. Field populations of A. leona larvae from districts in the Central region subjected to bifenthrin were susceptible at the recommended field rate $(0.0245 \%)$ for mirids after $48 \mathrm{~h}$ of exposure under laboratory conditions. The insecticide induced a median lethal concentration $\left(\mathrm{LC}_{50}\right)$ of $\leq 0.0061 \%$ and $\leq 0.0018 \%$ on A. leona larvae from Jukwa and Twifo Praso in the Central region at 24 and 48 $\mathrm{h}$ of exposure, respectively. Field application of bifenthrin was able to suppress infestation. The findings show that Anomis larvae were responsible for the outbreak, inducing extensive damage on pods. Bifenthrin was toxic to the

ARTICLE INFO

Article history:

Received: 9 July 2021

Accepted: 22 October 2021

Published: 21 December 2021

DOI: https://doi.org/10.47836/pjtas.45.1.04

larvae and could be used to manage them on the field. The outbreak indicates the need to develop an integrated management and monitoring strategy for cocoa pests to minimize future outbreaks.
\end{abstract}

Email addresses:

wintuma@live.com (Silas Wintuma Avicor)

r.aduacheampong@yahoo.co.uk (Richard Adu-Acheampong)

anthocyanin22@yahoo.com (Godfred Kweku Awudzi)

*Corresponding author
Keywords: Anomis leona, cocoa, Ghana, insecticide, pest outbreak 


\section{INTRODUCTION}

Although non-native to West Africa, cocoa (Theobroma cacao L.) is widely grown in the sub-region, with Cote D'Ivoire and Ghana being the two leading producers of the crop globally (Food and Agriculture Organization Corporate Statistical Database [FAOSTAT], 2019). It is the largest agricultural foreign exchange earner for Ghana raking in nearly US \$2 billion annually (Ghana Cocoa Board [COCOBOD], 2019) and a major source of employment for several individuals (Ghana Living Standards Survey [GLSS], 2014). With an estimated 800,000 households involved in cocoa production in Ghana (COCOBOD, 2019), market dynamics, especially concerning the price of cocoa, substantially affect the financial health of several households (Kolavalli et al., 2012; Vigneri \& Kolavalli, 2018). Sustaining the productivity of this sector is therefore of utmost importance to the Ghanaian economy.

However, cocoa production is severely affected by pests and diseases, resulting in substantial yield losses and invariably reducing the income of cocoa cultivation households and the nation's foreign exchange. The pests of cocoa include insects, such as mirids, stink bugs, mealybugs, coreid bugs, termites, and other lepidopteran larvae, which attack different parts and phenological stages of the crop (Awudzi et al., 2009). Crop losses due to these pests vary from about $18 \%$ for stink bugs (Owusu-Manu, 1976) to a reported $30-40 \%$ for mirids (Awudzi et al., 2016).

Management of cocoa insect pests is dominated by applying conventional insecticides (Adu-Acheampong et al., 2015). For instance, to mitigate the activities of pests and diseases and increase production, the Government of Ghana instituted the Cocoa High Technology (Hi-Tech) and Cocoa Disease and Pest Control (CODAPEC) programs, with the dual aim of subsidizing fertilizers and applying (spraying) pesticides for farmers respectively. However, these flagship programs have encountered some challenges, and CODAPEC is unable to completely meet the insecticide requirement of cocoa farmers leading to its augmentation by farmers with insecticides sourced from the open market (Anang et al., 2013; Aneani et al., 2012), a pathway for the usage of unapproved chemicals (Denkyirah et al., 2016).

Despite implementing various pest management methods, insect pest outbreaks occur due to several factors (Obeng-Ofori \& Afreh-Nuamah, 2007). In late 2018, farmers reported a larval outbreak on cocoa pods in some cocoa growing areas in Ghana. It was purported that this was due to applying an insecticide product containing fipronil to control cocoa insect pests. The larvae were reported to be chewing the pods of cocoa. Prior to the reported outbreak, fall armyworm had invaded Ghana. As a result, this larval outbreak was initially reported by farmers and extension personnel to be fall armyworms on cocoa. Hence it was important to identify the pest to aid in its control. Therefore, this study aimed to identify the pest responsible for the outbreak, the level of infestation and insecticide susceptibility of the pest to aid in remedial measures to suppress the outbreak and assist in mitigating future outbreaks. 


\section{MATERIALS AND METHODS}

\section{Survey Area}

The study was conducted in districts with reported pest outbreaks on cocoa pods in the Ashanti, Central, and Western regions of Ghana from September to December 2018 (Supplementary Data 1, Figure 1). Farms were selected within two communities per district (unless indicated otherwise) in heavily infested areas with the aid of District Officers/Community Extension Agents of the Cocoa Health and Extension Division (CHED) for assessment. Communities with the reported outbreak were in the following cocoa districts; Nyinahin, Enchi, Breman Asikuma, Twifo Praso, Assin Fosu, and
Jukwa (Supplementary Data 1). These districts have bimodal rainfall peaks usually occurring from April-July (major season) and August-November (minor season). The communities surveyed were Awiseso (Ny1), Achiase (Ny2), and Asuontaa (Ny3) in Nyinahin, Homaho (Homaho Farm 1 [AF1]), and Homaho Farm 2 [AF2]) in Assin Fosu, Kwamo (Kwamo Farm 1 [BA1] and Kwamo Farm 2 [BA2]) in Breman Asikuma, Watreso (Jk1), Asuoyenu (Jk2), and Bekawopa (Jk3) in Jukwa, Koraso (TP1) and Assin Adiembra (TP2) in Twifo Praso and Mile 4 (Enchi) in Enchi. The temperature and rainfall levels in these districts are presented in Supplementary Data 1.

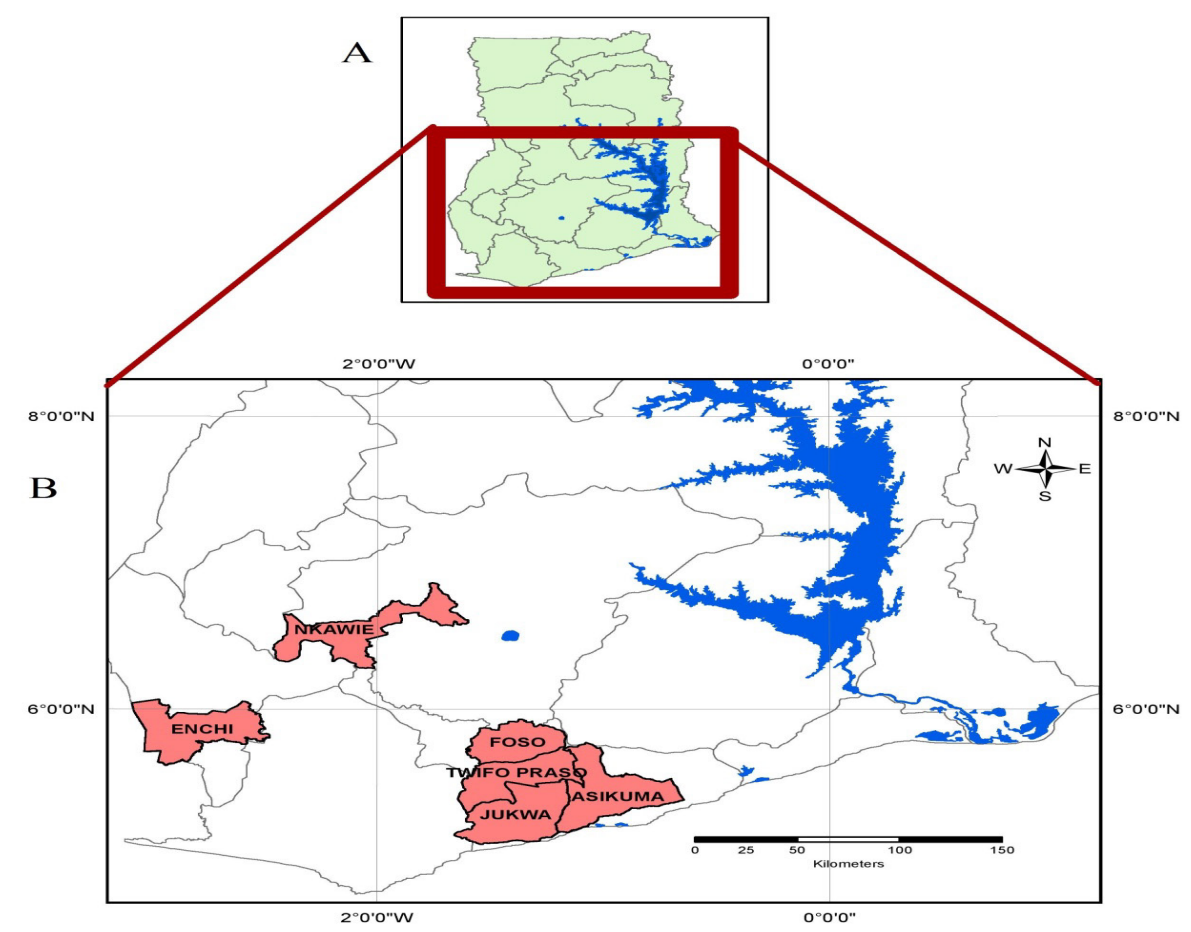

Figure 1. Map of Ghana (A) showing the cocoa districts (B) with the reported outbreak. Nyinahin district was recently carved out from Nkawie district

Note. Foso: Assin Fosu; Asikuma: Breman Asikuma 
Insect Pest Assessment and Collection

Thirty trees were randomly sampled per 0.5 acres in each farm (3 replicates per farm) and visually assessed at $2 \mathrm{~m}$ above ground level for insects and insect damage (Collingwood, 1971). All potential insectinhabiting sites like pods, pod peduncles, flower cushions, stem, and their interfaces within the sampling height were inspected. A tree was considered infested if the following was observed; damage by an insect pest, insect pest presence or both. The level of infestation by a particular insect pest was estimated as below:

$\%$ Tree infestation $=($ Number of trees infested by pest/Number of trees sampled) $\mathrm{x} 100 \%$
Larvae [via brushing into collection containers (top diameter $=19 \mathrm{~cm}$, height $=21.6 \mathrm{~cm}$, and bottom diameter $=16 \mathrm{~cm})]$ and larvae-infested cocoa pods (30 per farm, thus 10 Anomis-infested, 10 Eariasinfested, and 10 Characoma-infested pods) were collected from the farms and reared to adult in containers (same dimension as collection container) in the insectary at Cocoa Research Institute of Ghana (CRIG), New Tafo-Akim at $25-30{ }^{\circ} \mathrm{C}, 70-85 \%$ relative humidity (RH), and 12: $12 \mathrm{~h}$ light: dark (L: D) photoperiod. Green succulent cocoa leaves (daily) and pods (every three days) were fed to the larvae until adult emergence. Adult emergence for a specific insect pest was estimated as follows:

$$
\text { Adult emergence }(\%)=\frac{\text { Number of pod-infested larvae with adult emergence }}{\text { Total number of pod-infested larvae sampled for the pest }} \times 100 \%
$$

Identification was made based on morphological features of the larvae and adults using the keys and images in Awudzi et al. (2009), Entwistle (1972), Ferreira et al. (2015), Mkhize (1971), and Schuh (2013).

\section{Insecticide Susceptibility Tests of Field Populations}

Larval samples from the study area except the Central region were insufficient for the susceptibility tests. Hence, Anomis larvae from this region were used for the tests. Larvae ( $4^{\text {th }}$ instar) of $A$. leona from farms in each district were pooled for the district and used for the tests. An insecticide product containing bifenthrin
(27 g/L) was selected for the susceptibility tests due to bifenthrin's toxicity to insects (Johnson et al., 2010), approval for use against cocoa mirids in Ghana and wide usage across the cocoa landscape (Awudzi et al., 2009). The product's recommended field concentration $(0.0245 \%)$ for mirids was used $(1 \mathrm{ml})$ to impregnate Whatman No. 1 filter paper in Petri dishes. Larvae (5) of $A$. leona were exposed to the papers (Ackonor \& Adu-Acheampong, 2007) for 24 and $48 \mathrm{~h}$ to observe mortality. Samples from Jukwa and Twifo Praso were used for the dose-mortality test due to the inadequate number of larvae from the other sites. The dose-mortality response was determined 
as follows: four concentrations $(0.03768 \%$, $0.0205 \%, 0.006 \%$, and $0.0015 \%)$ of the insecticide were prepared and used $(1 \mathrm{ml})$ to impregnate Whatman No. 1 filter paper in Petri dishes. The concentrations were selected based on their ability to induce larval mortality of $10-100 \%$ in a preliminary test. Larvae (5) of A. leona were exposed to the insecticide-treated papers for 24 and $48 \mathrm{~h}$ and mortality was noted afterwards. Larvae exposed to filter paper impregnated with distilled water $(1 \mathrm{ml})$ for 24 and $48 \mathrm{~h}$ were used as controls. Three replicates were performed for each concentration and control. The testing condition was $25{ }^{\circ} \mathrm{C}-27{ }^{\circ} \mathrm{C}$, 70-85\% RH, and 12: $12 \mathrm{~h} \mathrm{L:} \mathrm{D} \mathrm{photoperiod.}$

\section{Field Application of Insecticide}

The extensive nature of the outbreak required chemical control to suppress the pest population quickly. Based on the results of the susceptibility tests, the bifenthrinbased insecticide was applied at $100 \mathrm{ml}$ in $11 \mathrm{~L}$ of water for 0.5 acres at monthly intervals for two months in the outbreak areas. Application of the insecticide was made using a motorized mist blower with every row application technique (Awudzi et al., 2012). Assessment of Anomis larvae infestation of cocoa was done before and at $48 \mathrm{~h}$ after each application. It was done by randomly selecting 30 cocoa trees per 0.5 acres and visually inspecting the pods and trees from 0 to $2 \mathrm{~m}$ above ground level for the presence of the larvae or signs of their damage.

\section{Data Analysis}

The proportion of infested cocoa trees for each insect pest was computed for each farm as the ratio of infested trees to the total number of sampled cocoa trees. Larval mortality at the recommended concentration was arcsine transformed and subjected to analysis of variance (ANOVA) using IBM SPSS ver. 20. Mortality data for the dose-response effect was used to compute the median lethal concentration $\left(\mathrm{LC}_{50}\right)$ using Insecticide Resistance Monitoring Application-QCal (IRMA-QCal) (LozanoFuentes et al., 2012). LC L $_{50}$ values with overlapping $95 \%$ confidence intervals (CIs) were considered not significantly different (Asekunowo et al., 2018). Finally, the number of trees infested by Anomis larvae before and after insecticide application on the field was computed using the tree infestation (\%) formula above.

\section{RESULTS}

\section{Insect Damage and Species Composition}

Insect damage on the pod include feeding channels/tunnels on the pericarp due to chewing activity (horizontal and vertical) by Anomis leona and Earias biplaga and holes on pods with many frasses covering the entrance caused by the boring activity of the pod borer Characoma spp. (Supplementary Data 2). Feeding lesions (water-soaked depressions) were also observed on pods, and this was caused by the nymphs and adults of mirids (Sahlbergella singularis Haglund, Distantiella theobroma Distant, 
and Helopeltis spp.) and coreid bugs (Pseudotheraptus devastans Distant) when they suck sap from the pod. The feeding lesions could coalesce to form a large patch. The lesions caused by coreid bugs were larger than those of mirids. Some of the pods also looked deformed/malformed, a symptom of coreid bug infestation. Some immature pods were observed to show signs of ripening, a condition known as premature ripening, and this is caused by the feeding (sucking) activity of stink bugs (Bathycoelia thalassina Herrich-Schaeffer) (Supplementary Data 2).

Holes were also observed on the trunk and branches of the cocoa tree within the sampling height, with many frasses at the entrance of the hole and base of the tree. This is a typical damage due to the boring activity of the larvae of the stem borer. Cocoa trees were also defoliated by the chewing activity of $A$. leona and E. biplaga (Supplementary Data 2).

Insects observed to be feeding on cocoa pods on the farms include nymphs and adults of mirids ( $S$. singularis, $D$. theobroma, and Helopeltis spp.), larvae of lepidopterans (A. leona, E. biplaga, and Characoma spp.), nymphs and adults of stink bug (B. thalassina Herrich-Schaeffer) and nymphs and adults of coreid bug ( $P$. devastans Distant).

\section{Infestation Level}

About $96 \%$ of the sampled cocoa trees in Mile 4 in Enchi district in the Western region were infested with Anomis, while mirids and Earias infestation of the trees were $60 \%$ and $68 \%$, respectively. Pod borer, coreid, and stink bugs infestations were less than 20\%. Stem borer infestation was not observed on this farm (Figure 2). Pod borer infestation was highest in Ny1 while Earias infestation dominated (96\% and $100 \%)$ in the other two farms in Nyinahin district in the Ashanti region (Figure 2). Anomis infestation was the second-highest in all the three farms in the district. Infestation by mirids was observed in all the sampled farms in this district, while stink bug and stem borer infestations were observed in only $\mathrm{Ny} 3$ and Ny2 at 4\% each, respectively.

Anomis infestation dominated in seven out of the nine farms in the Central region, with coreid bug and Earias infestation dominating the other two farms (Figure 3). High Anomis infestations (88\%-96\%) were observed in farms in Breman Asikuma (BA2), Twifo Praso (TP1 and TP2), and Jukwa (Jk2). In Assin Fosu, Anomis (76\%), Earias (52\%), and Characoma caused the most infestations at AF1. However, in AF2, infestations were mostly caused by coreid bugs (72\%), Anomis (40\%), and Earias (24\%). The most common infestations in Breman Asikuma were caused by Anomis (68\%), Earias (52\%), and stink bugs (20\%) in BA1 and Anomis (96\%), Earias (40\%), and pod borer (28\%) in BA2. Infestation of cocoa in the Jukwa district was dominated by Anomis, Earias, and coreid bug at $40 \%$, $48 \%$, and $32 \%$ in $\mathrm{Jk} 1,88 \%, 12 \%$, and $44 \%$ in $\mathrm{Jk} 2$ and $80 \%, 24 \%$, and $8 \%$ at $\mathrm{Jk} 3$. Anomis, Earias, and coreid bug infestations occurred at $88 \%, 56 \%$, and $20 \%$ in TP1 and $96 \%, 44 \%$, and $36 \%$ in TP2.

Generally, Anomis infestation was the most dominant on cocoa pods in the outbreak communities, followed by Earias 
(Figure 4). Lower infestation levels by lepidopterans A. leona (8.5\%), E. biplaga the other insect pests were also observed (3.1\%), and Characoma stictigrapha $(2.7 \%)$ on cocoa pods. Insects that emerged from (Supplementary Data 2). the reared larvae/incubated pods were the

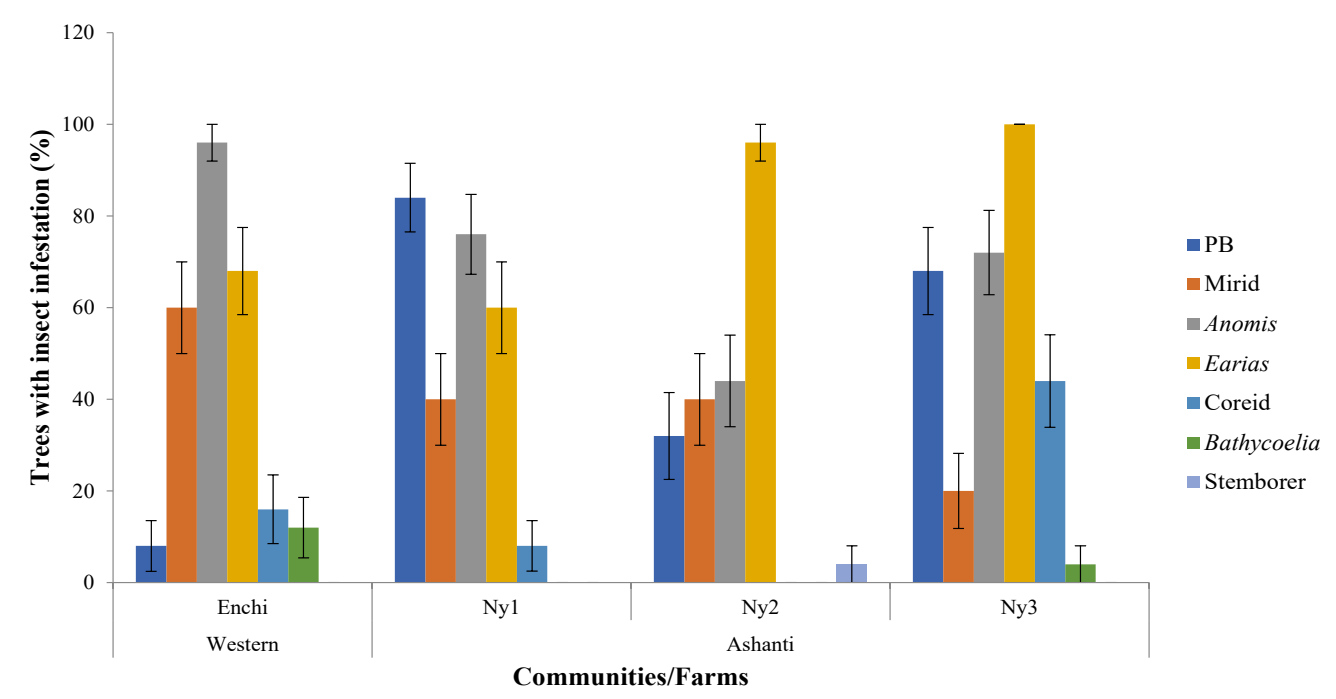

Figure 2. Mean insect pest infestation level of cocoa trees in Ashanti and Western regions of Ghana. The error bars denote standard error

Note. Ny1: Nyinahin Farm 1; Ny2: Nyinahin Farm 2; Ny3: Nyinahin Farm 3; PB: Pod borer

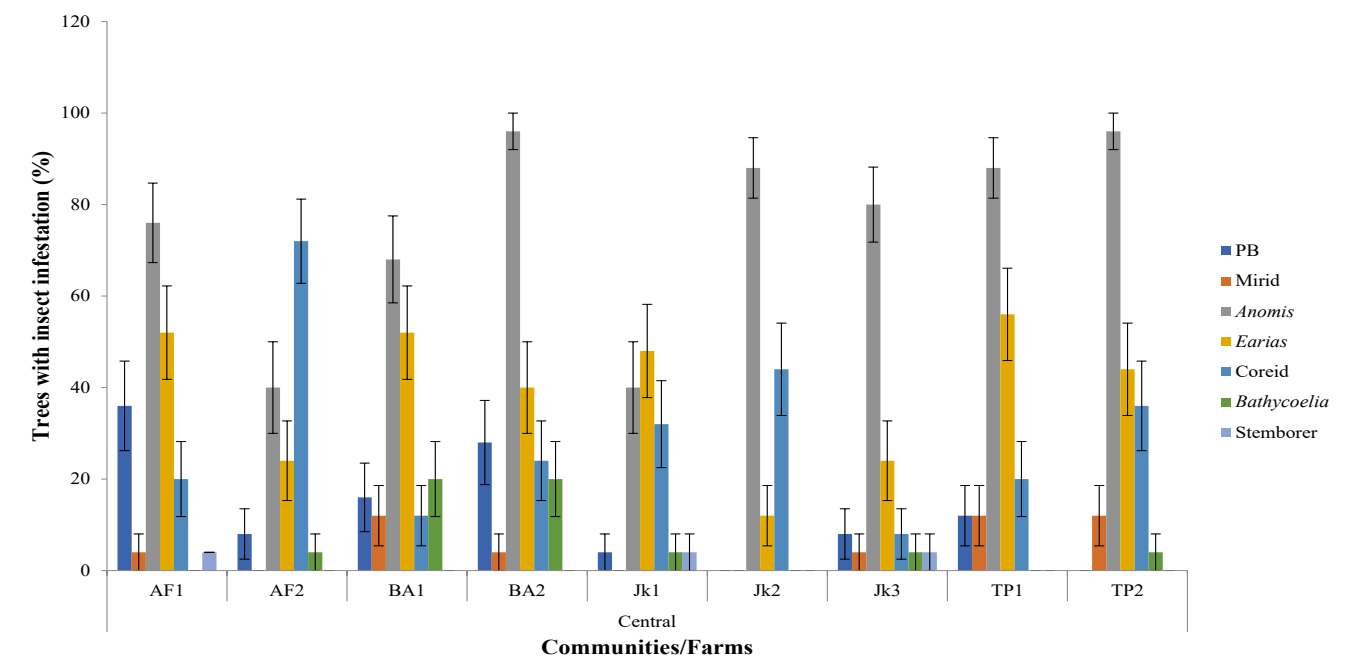

Figure 3. Mean insect pest infestation level of cocoa trees in the Central region of Ghana. The error bars denote standard error

Note. AF1: Assin Fosu Farm 1; AF2: Assin Fosu Farm 2; BA1: Breman Asikuma Farm 1; BA2: Breman Asikuma Farm 2; Jk1: Jukwa Farm 1; Jk2: Jukwa Farm 2: Jk3: Jukwa Farm 3; TP1: Twifo Praso Farm 1; TP2: Twifo Praso Farm 2; PB: Pod borer 


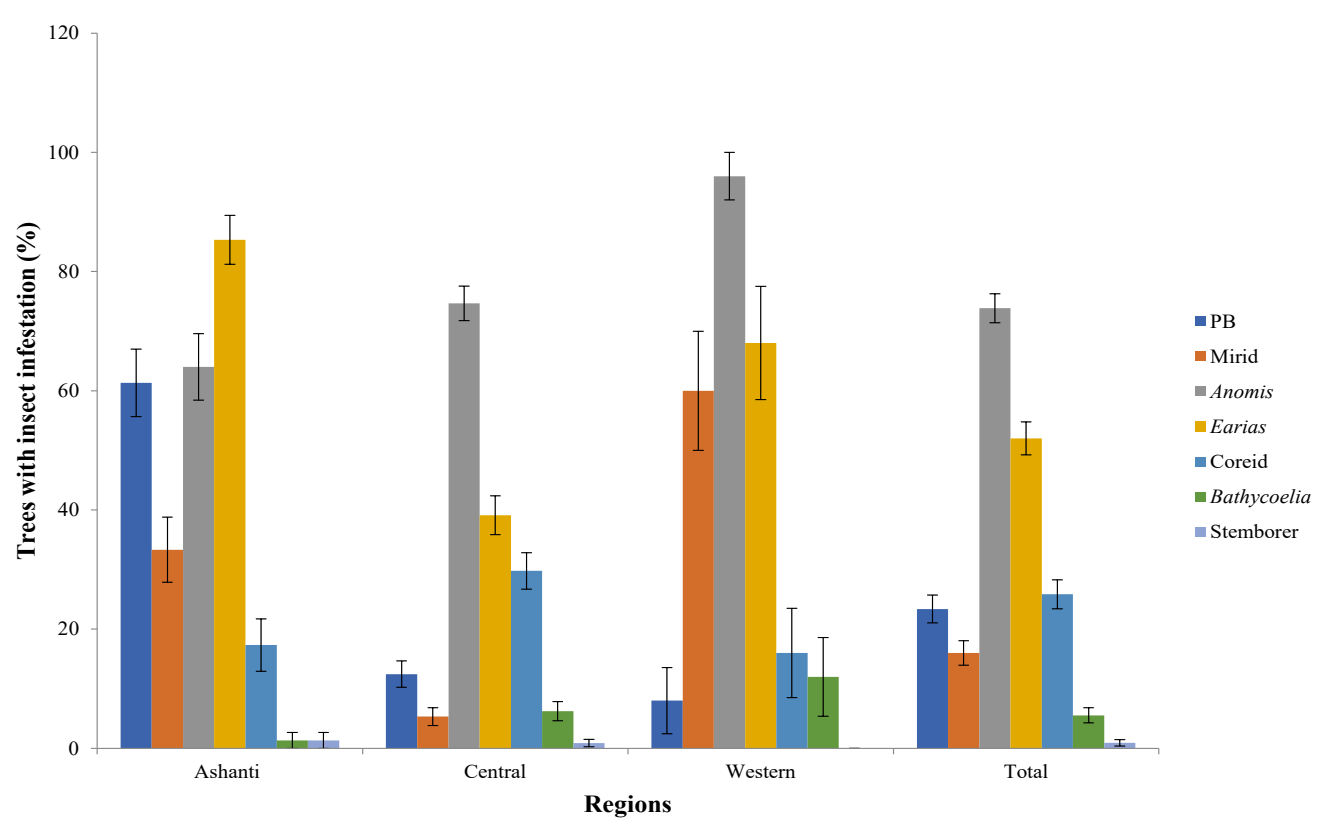

Figure 4. Mean insect pest infestation level of cocoa trees in the outbreak areas. The error bars denote standard error. Ashanti region $(C=3, N=3)$, Central region $(C=7, N=9)$, Western region $(C=1, N=1)$

Note. $\mathrm{C}=$ Number of communities; $\mathrm{N}=$ Number of farms sampled; PB: Pod borer

\section{Susceptibility to Bifenthrin}

Larval mortality for the controls was $0 \%$. At the recommended label concentration of the bifenthrin product, larvae of $A$. leona from Breman Asikuma were highly susceptible at an exposure period of $24 \mathrm{~h}$ (Table 1). Larval mortality for the other localities ranged between $73 \%$ and $88 \%$. When insecticide exposure was prolonged to $48 \mathrm{~h}$, mortality of $93 \%$ to $100 \%$ was observed (Table 1 ). The mortality rates for the larval populations were not significantly different at 24 ( $p=$ $0.053)$ and $48 \mathrm{~h}(p=0.441)$. The $\mathrm{LC}_{50}$ at $24 \mathrm{~h}$ for $A$. leona larvae from Jukwa and Twifo Praso was $0.0026 \%$ and $0.0061 \%$, respectively, but these were not significantly different (Table 2).

Table 1

Mortality of Anomis leona larvae after exposure (24 and 48 h) to recommended label concentration of bifenthrin

\begin{tabular}{lcc}
\hline District & \multicolumn{2}{c}{ Mortality \pm SE (\%) } \\
\cline { 2 - 3 } & $24 \mathrm{~h}$ & $48 \mathrm{~h}$ \\
\hline Assin Fosu & $86.67 \pm 6.67$ & $100 \pm 0.00$ \\
Breman Asikuma & $100 \pm 0.00$ & $100 \pm 0.00$ \\
Jukwa & $73.33 \pm 6.67$ & $93.33 \pm 6.67$ \\
Twifo Praso & $88.33 \pm 3.86$ & $93.33 \pm 1.67$ \\
\hline
\end{tabular}

Note. Recommended label concentration was $0.0245 \%$; SE: Standard Error 
Table 2

Bifenthrin toxicity to Anomis leona larvae at different exposure durations

\begin{tabular}{ccccc}
\hline $\begin{array}{c}\text { Exposure } \\
\text { duration }(\mathrm{h})\end{array}$ & $\begin{array}{c}\text { Larval } \\
\text { population }\end{array}$ & $\begin{array}{c}\mathrm{LC}_{50}(\%) \\
{[95 \% \mathrm{CI}]}\end{array}$ & Slope $\pm \mathrm{SE}$ & Intercept $\pm \mathrm{SE}$ \\
\hline 24 & Jukwa & 0.0026 & $0.6282 \pm 0.2404$ & $3.7330 \pm 1.2292$ \\
& & {$[0.0008-0.0085]$} & & \\
& Twifo Praso & 0.0061 & $1.4339 \pm 0.3401$ & $7.3223 \pm 1.6978$ \\
& & {$[0.0037-0.0099]$} & & \\
48 & Jukwa & 0.0003 & $0.5376 \pm 0.3058$ & $4.4131 \pm 1.6512$ \\
& & {$[0-0.0095]$} & & \\
& Twifo Praso & 0.0018 & $1.2187 \pm 0.3687$ & $7.7355 \pm 1.6512$ \\
& & {$[0.0008-0.0037]$} & & \\
\hline
\end{tabular}

Note. $\mathrm{LC}_{50}$ : Median lethal concentration; CI: Confidence interval; SE: Standard error

\section{Field Management of Pest}

The insecticide was effective against Anomis larvae in the field, inducing knockdown and significantly reducing larval infestation of cocoa pods after 48 hours. New larval damage on pods was also not observed. There was a further reduction in Anomis infestation of the cocoa trees in the treated farms after the second application (Figure 5).

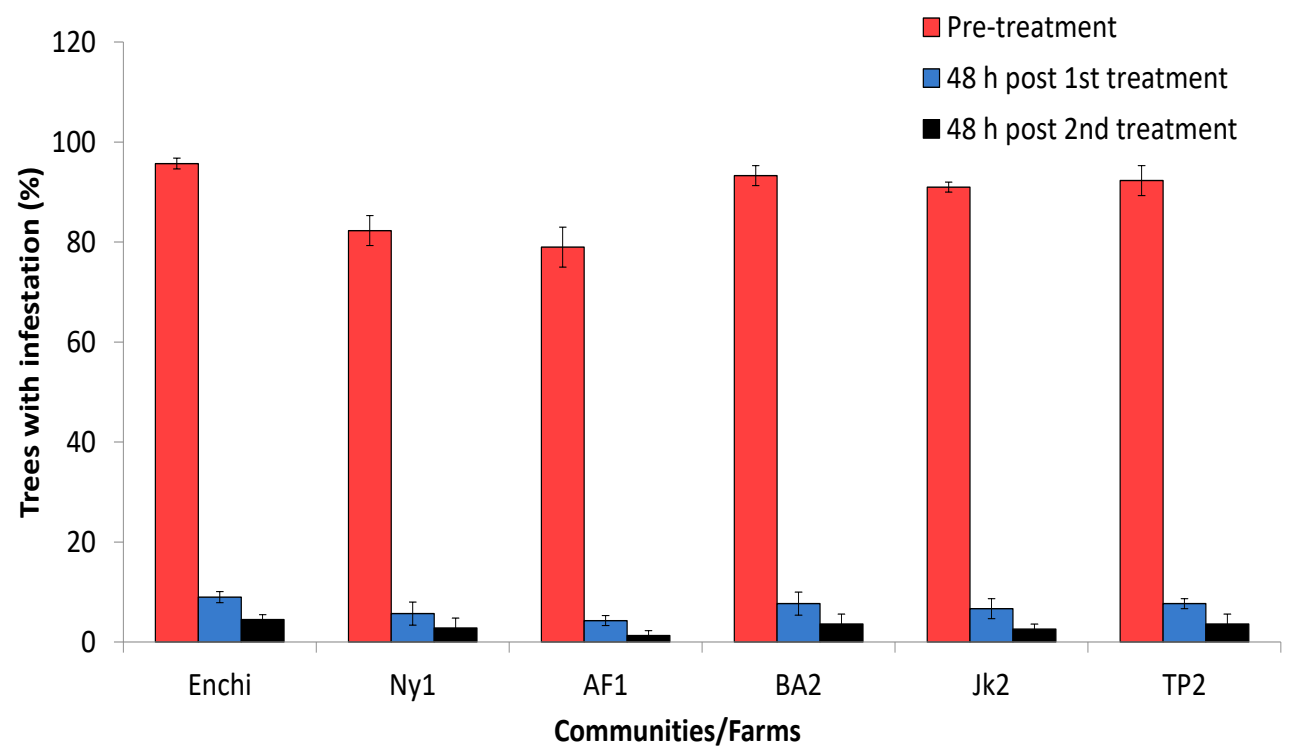

Figure 5. Mean level of infestation of cocoa by Anomis larvae in the study sites. The error bars denote standard error

Note. Ny1: Nyinahin Farm 1; AF1: Assin Fosu Farm 1; BA2: Breman Asikuma Farm 2; Jk2: Jukwa Farm 2; TP2: Twifo Praso Farm 2 


\section{DISCUSSION}

Pest outbreak is caused by several biotic and abiotic factors, including innate biological capability, topography, host plant, plant architecture, climatic/weather conditions, and pest density (Creeden et al., 2014; Singh \& Satyanarayana, 2009). An assessment of the outbreak indicated damage diagnostic of larvae of Anomis and Earias, although damage by other insect pests was also observed. The infestation levels varied among the outbreak areas for different insect pest species. Most (96\%) of the cocoa trees in Mile 4 in the Enchi district were attacked by Anomis larvae. Damage by Anomis was pervasive in the Central region irrespective of the district sampled. The predominance of lepidopteran (Characoma spp., E. biplaga, and $A$. leona) damage on cocoa pods was conspicuous in the Nyinahin district in the Ashanti region. Although Characoma infestation dominated in one sampled site and Earias infestation dominated in the other two, infestation by Anomis in the district was higher than that of Characoma and only second to Earias. In farms in Twifo Praso and Assin Fosu, nearly all the sampled cocoa trees were attacked by Anomis. Herbivory activities of Anomis larvae were on the pods and leaves. Defoliation by Anomis larvae reduces the photosynthetic ability of the plant. However, of imminent concern was the pod-feeding activity of the larvae since young cocoa pods that are attacked may stop growing due to the extensive damage. Similarly, pod feeding and folivory by larvae of Earias biplaga can adversely affect the plant and result in yield reduction. The holes created by Anomis and Earias and the feeding lesions by mirids are likely to be exploited by fungi (Afreh-Nuamah, 1999; Sarfo \& Opoku, 2006) to cause pod rot. Since the pods and specifically the beans of cocoa are the most valued parts, the activities of these insects would invariably affect yield.

Reports from extension (CHED) officers and farmers in the affected communities indicate that before the outbreak, an insecticide product containing fipronil was used to control insect pests of cocoa, particularly mirids and other Hemipterans. Although the product was effective, an upsurge in lepidopteran larvae on cocoa pods was observed afterwards and hence the perception that the said product might have eliminated natural enemies of the larvae leading to their increased population on cocoa. However, besides the toxicity of some pesticides to natural enemies (either directly and/or indirectly through consuming pesticide-tainted prey), pesticides can also increase pest populations through processes, such as hormesis (Raupp et al., 2010; Szczepaniec et al., 2011) and the enhanced nutritive value or suitability of host plants to herbivores by inducing physiological alterations in plants (Gupta \& Krischik 2007; Raupp et al., 2010). Contrastingly, a farm in one of the outbreak communities (Jukwa) in which the fipronil product was also used was unaffected by the outbreak. Hence, concluding on the cause of an outbreak without concrete evidence is problematic since the factors that account for pest outbreaks are enigmatic. 
Although pod feeding was more pronounced and preferred in this outbreak, similar to the observation of Sarfo and Opoku (2006), larvae of Anomis and Earias also defoliate cocoa (Awudzi et al., 2009). If uncontrolled, the outbreak of defoliators may contribute to tree decline and eventually tree mortality (Asaro \& Chamberlain, 2015). Although mortality due to defoliation is difficult to establish due to the interplay of factors, a positive relationship between the frequency and severity of defoliation and tree mortality has been established (Asaro $\&$ Chamberlain, 2015). The Western region, which was the first to report the outbreak, has previously had an $A$. leona outbreak over a decade ago in Bibiani district (Sarfo \& Opoku, 2006). Pest outbreaks are complex and difficult to predict, and as reviewed by Asaro and Chamberlain (2015), they could occur in the same region in subsequent or different years by the same pests. Therefore, it is important to develop a monitoring system to detect incipient population buildup and forecast outbreaks.

Although several lepidopteran larvae were found to be infesting cocoa pods, $A$. leona and E. biplaga were the most common and occurred simultaneously in the sampled locations. This phenomenon is not rare and is reported in other countries (Asaro \& Chamberlain, 2015; Ciesla \& Asaro, 2013). Despite the co-occurrence of both larvae, A. leona was the most dominant. The perception of secondary infestation by farmers and extension staff could result from a disruption in the cyclic pest-natural enemy interaction, which could be due to a spatial (Maron et al., 2001) or temporal escape of the pest from its natural enemies. The outbreak could have also been triggered by predisposing factors, such as reduced resistance of the trees, albeit temporary and the abundance of suitable food for the pests, such as flushes for defoliators like $A$. leona and E. biplaga. Anomis and Earias are of minor importance in cocoa production in Ghana compared to mirids, stink bugs and coreid bugs. The larvae of Anomis and Earias are occasional pests. They are usually observed at the onset of the rains when flushes emerge, a food substrate for the larvae. Defoliator abundance, therefore, tends to increase with the abundance of flushes; hence, the inability to initiate control measures might have led to the build-up of the pests and dispersion to other substrates, such as the pods. Simplification of agricultural ecosystems, such as cocoa through monoculture, makes them prone to pest outbreaks (Obeng-Ofori \& AfrehNuamah, 2007). Hence, in the absence of host resistant planting varieties, insect pest outbreaks could be mitigated via mixed systems, such as agroforestry or mixed cropping (Crowder \& Jabbour, 2014; Klapwijk \& Bjorkman, 2018) and strict adherence to integrated crop management systems.

During outbreaks, prompt action involving insecticides is of importance since it is a quicker means of suppressing the pest if the insecticides are efficacious and help avoid escalation of the outbreak. Bifenthrin was toxic to field-collected $A$. leona larvae and, hence, suitable as an effective agent 
for controlling the outbreak. The $24 \mathrm{~h} \mathrm{LC}_{50}$ values of $0.0026 \%$ and $0.0061 \%$ on $A$. leona larvae from Jukwa and Twifo Praso, respectively, compared favourably with that (24 $\mathrm{h} \mathrm{LC}_{50}$ of $0.00558 \%$ ) of an insecticide susceptible strain of the fruit fly Bactrocera zonata (Ahmad et al., 2010). Bifenthrin was more toxic to the test larvae in this study compared to pests, such as the spider mite Tetranychus urticae $\left(\mathrm{LC}_{50}\right.$ of $\left.0.00753 \%\right)$ (Wang et al., 2014) and field strains of $B$. zonata $\left(\mathrm{LC}_{50} \mathrm{~s}\right.$ of 0.04586 and $0.05333 \%$ ), although the testing methods differed.

Bifenthrin is commonly used against mirids and other cocoa insect pests (AduAcheampong et al., 2015; Antwi-Agyakwa et al., 2015; Awudzi et al., 2016). It quickly knocks down insects before inducing mortality. Its efficacy on Anomis larvae under laboratory and field conditions indicates that it could be used as a control agent against the pest. However, documented information on A. leona and E. biplaga in Ghana is limited. The recent outbreak highlights the urgent need for investigations into this pest's population dynamics and bio-ecology and exploration for effective but eco-friendly management practices to control it on cocoa sustainably.

\section{CONCLUSION}

Larvae of Anomis leona predominantly caused a caterpillar outbreak on cocoa pods in Ghana in 2018. The larvae consumed the pericarp of the pods causing extensive damage that warranted control. Field populations of A. leona were susceptible to bifenthrin under laboratory conditions, and field application of the insecticide was able to suppress the outbreak. Developing an integrated pest management approach would help in effectively managing pests with less emphasis on synthetic insecticide usage. It is equally important to develop a monitoring and forecasting system for early pest detection and prediction of outbreaks.

\section{ACKNOWLEDGEMENTS}

The assistance of the Cocoa Health and Extension Division (CHED) and Entomology Division of the Cocoa Research Institute of Ghana (CRIG) is appreciated. In addition, the authors acknowledge the assistance of Mr Yaw Dankwa Nkroma in generating the map. This paper is published with the kind permission of the Executive Director of CRIG (CRIG/03/2020/054/001).

\section{REFERENCES}

Ackonor, J. B., \& Adu-Acheampong, R. (2007). Standard protocol for screening conventional insecticides at the Cocoa Research Institute of Ghana for mirid control. Journal of the Ghana Science Association, 9(2), 117-121. https://doi. org/10.4314/jgsa.v9i2.18020

Adu-Acheampong, R., Sarfo, J. E., Appiah, E. F., Nkansah, A., Awudzi, G., Obeng, E., Tagbor, P., \& Sem, R. (2015). Strategy for insect pest control in cocoa. American Journal of Experimental Agriculture, 6(6), 416-423. https:// doi.org/10.9734/AJEA/2015/12956

Afreh-Nuamah, K. (1999). Insect pests of tree crops in Ghana: Identification, damage and control measures. Buck Press.

Ahmad, S. F., Ahmed, S., Khan, R. R., \& Nadeem, M. K. (2010). Evaluation of insecticide resistance in two strains of fruit fly, Bactrocera zonata 
(Saunders) (Tephritidae: Diptera), with fruit dip method. Pakistan Entomologist, 32(2), 163-167.

Anang, B. T., Mensah, F., \& Asamoah, A. (2013). Farmers' assessment of the government spraying program in Ghana. Journal of Economics and Sustainable Development, 1(7), 92-99.

Aneani, F., Anchirinah, V. M., Owusu-Ansah, F., \& Asamoah, M. (2012). Adoption of some cocoa production technologies by cocoa farmers in Ghana. Sustainable Agriculture Research, 1(1), 103-117. https://doi.org/10.5539/sar.v1n1p103

Antwi-Agyakwa, A. K., Osekre, E. A., AduAcheampong, R., \& Ninsin, K. D. (2015). Insecticide use practices in cocoa production in four regions in Ghana. West African Journal of Applied Ecology, 23(1), 39-48.

Asaro, C., \& Chamberlain, L.A. (2015). Outbreak history (1953-2014) of spring defoliators impacting oak-dominated forests in Virginia, with emphasis on gypsy moth (Lymantria dispar L.) and fall cankerworm (Alsophila pometaria Harris). American Entomologist, 61(3), 174-185. https://doi.org/10.1093/ae/tmv043

Asekunowo, P. O., Haque, R. A., Razali, M. R., Avicor, S. W., \& Wajidi, M. F. F. (2018). Synthesis and characterization of nitrile functionalized silver(I)- $N$-heterocyclic carbene complexes: DNA binding, cleavage studies, antibacterial properties and mosquitocidal activity against the dengue vector, Aedes albopictus. European Journal of Medicinal Chemistry, 150, 601-615. https://doi.org/10.1016/j.ejmech.2018.03.029

Awudzi, G. K., Ackonor, J. B., Cudjoe, A. R., Dwomoh, E. A., \& Sarfo, J. E. (2009). Manual for cocoa insect pests, symptoms of their damage and methods of their control. Cocoa Research Institute of Ghana.

Awudzi, G. K., Cudjoe, A. R., Assuah, M. K., AduAcheampong, R., Dwomoh, E. A., Adu-Yeboah, P., \& Sarfo, J. E. (2012). Pesticide use in cocoa cultivation in Ghana. Cocoa Research Institute of Ghana.
Awudzi, G. K., Asamoah, M., Owusu-Ansah, F., Hadley, P., Hatcher, P. E., \& Daymond, A. J. (2016). Knowledge and perception of Ghanaian cocoa farmers on mirid control and their willingness to use forecasting systems. International Journal of Tropical Insect Science, 36(1), 22-31. https://doi.org/10.1017/ S1742758415000247

Ciesla, W. M., \& Asaro, C. (2013). Fall cankerworm. https://www.fs.usda.gov/Internet/FSE_ DOCUMENTS/stelprdb5426975.pdf

Collingwood, C. A. (1971). A comparison of assessment methods in cocoa mirid count trials. In Proceedings of 3rd International Cocoa Research Conference (p. 161). Cocoa Research Institute of Ghana.

Creeden, E. P., Hicke, J. A., \& Buotte, P. C. (2014). Climate, weather, and recent mountain pine beetle outbreaks in the western United States. Forest Ecology and Management, 312, 239-251. https://doi.org/10.1016/j.foreco.2013.09.051

Crowder, D. W., \& Jabbour, R. (2014). Relationships between biodiversity and biological control in agroecosystems: Current status and future challenges. Biological Control, 75, 8-17. https:// doi.org/10.1016/j.biocontrol.2013.10.010

Denkyirah, E. K., Okoffo, E. D., Adu, D. T., Aziz, A. A., Ofori, A., \& Denkyirah, E. K. (2016). Modeling Ghanaian cocoa farmers' decision to use pesticide and frequency of application: The case of Brong-Ahafo Region. SpringerPlus, 5(1), 1113. https://doi.org/10.1186/s40064-0162779-z

Entwistle, P. F. (1972). Pests of cocoa. Longman Group Ltd.

Ferreira, P. S. F., Henry, T. J., \& Coelho, L. A. (2015). Plant bugs (Miridae). In A. Panizzi \& J. Grazia (Eds.), True bugs (Heteroptera) of the Neotropics (pp. 237-286). Springer. https://doi. org/10.1007/978-94-017-9861-7 
Food and Agriculture Organization Corporate Statistical Database. (2019). FAOSTAT. http:// www.fao.org/faostat/en/\#data/QC

Ghana Cocoa Board. (2019). Cocoa. COCOBOD.

Ghana Districts. (2017). Aowin Municipal Assembly. https://www.ghanadistricts.com/Home/ LinkDataDistrict/2729

Ghana Living Standards Survey. (2014). Ghana Living Standards Survey Round 6 - Main report. GLSS. http://www.statsghana.gov.gh/ gssmain/fileUpload/Living\%20conditions/ GLSS6_Main\%20Report.pdf

Ghana Statistical Service. (2014). 2010 Population and housing census: District analytical report - Assin North Municipal. GSS. https://newndpc-static1.s3.amazonaws.com/CACHES/ PUBLICATIONS/2016/06/06/Assin+North.pdf

Gupta, G., \& Krischik, V. A. (2007). Professional and consumer insecticides for the management of adult Japanese beetle on hybrid tea rose. Journal of Economic Entomology, 100(3), 830-837. https://doi.org/10.1093/jee/100.3.830

Johnson, M., Luukinen, B., Gervais, J., Buhl, K., \& Stone, D. (2010). Bifenthrin technical fact sheet. http://npic.orst.edu/factsheets/archive/ biftech.html

Klapwijk, M. J., \& Björkman C. (2018). Mixed forests to mitigate risk of insect outbreaks. Scandinavian Journal of Forest Research, 33(8), 772-780. https://doi.org/10.1080/02827581.2018.1502805

Kolavalli, S., Vigneri, M., Maamah, H., \& Poku, J. (2012). The partially liberalized cocoa sector in Ghana: producer price determination, quality control, and service provision. International Food Policy Research Institute (IFPRI). http://www. cocoaconnect.org/sites/default/files/publication/ kolavalli\%20et\%20al\%20\%282012\%29\%20 the $\% 20$ partically $\% 20$ liberalized $\% 20$ cocoa $\% 20$ sector\%20in\%20Ghana.pdf

Lozano-Fuentes, S., Saavedra-Rodriguez, K., Black, W. C. IV, \& Eisen, L. (2012). QCal:
A software application for the calculation of dose-response curves in insecticide resistance bioassays. Journal of the American Mosquito Control Association, 28(1), 59-61. https://doi. org/10.2987/11-6192.1

Maron, J. L., Harrison, S., \& Greaves, M. (2001). Origin of an insect outbreak: Escape in space or time from natural enemies?. Oecologia, 126(4), 595-602. https://doi.org/10.1007/ s004420000558

Mkhize, S. B. V. (1971). Studies on the lepidoptera of cocoa farms in Ghana [Unpublished Master's thesis]. University of Ghana.

Ministry of Food and Agriculture. (n.d. a). Atwima Mponua District. http://mofa.gov.gh/site/ directorates/district-directorates/ashantiregion/153-atwima-mponua

Ministry of Food and Agriculture. (n.d. b). TwifoHemang Lower Denkyira District. http://mofa. gov.gh/site/directorates/district-directorates/ central-region/215-twifo-herman-lowerdenkyira

Ministry of Food and Agriculture. (n.d. c). AsikumaOdoben-Brakwa District. http://mofa.gov. $\mathrm{gh} /$ site/sports/district-directorates/centralregion/201-asikuma-odoben-brakwa

Obeng-Ofori, D., \& Afreh-Nuamah, K. (2007). Crop pests and pest management. In D. Obeng-Ofori (Ed.), Major pests of food and selected fruit and industrial crops in West Africa (pp. 1-44). City Publishers.

Owusu-Manu, E. (1976). Estimation of cocoa pod losses caused by Bathycoelia thalassina (Herrich - Schaeffer) (Hemiptera, Pentatomidae). Ghana Journal of Agricultural Science, 9(2), 81-83.

Raupp, M. J., Shrewsbury, P. M., \& Herms, D. H. (2010). Ecology of herbivorous arthropods in urban landscapes. Annual Review of Entomology, 55, 19-38. https://doi.org/10.1146/annurevento-112408-085351 
Sarfo, J. E., \& Opoku I. Y. (2006). Report on an unusual attack on cocoa by a defoliator, Anomis leona Schaus (Coleoptera: Noctuidae), in Ghana. In A. Y. Akrofi \& F. Baah (Eds.), Proceedings of INCOPED $5^{\text {th }}$ International Seminar on Cocoa Pests and Diseases (pp. 114-117). Cocoa Research Institute of Ghana. https:// www.incocoa.org/data/incoped_workshop_5_ proceedings_2006.pdf

Schuh, R. T. (2013). On-line systematic catalog of plant bugs (Insecta: Heteroptera: Miridae). http://research.amnh.org/pbi/catalog/

Singh, T. V. K., \& Satyanarayana, J. (2009). Insect outbreaks and their management. In R. Peshin \& A. K. Dhawan (Eds.), Integrated pest management: Innovation-development process (pp. 331-350). Springer. https://doi. org/10.1007/978-1-4020-8992-3_13
Szczepaniec, A., Creary, S. F., Laskowski, K. L., Nyrop, J. P., \& Raupp, M. J. (2011). Neonicotinoid insecticide imidacloprid causes outbreaks of spider mites on elm trees in urban landscapes. PLOS One, 6(5), e20018. https://doi. org/10.1371/journal.pone.0020018

Vigneri, M., \& Kolavalli, S. (2018). Growth through pricing policy: The case of cocoa in Ghana. Food and Agriculture Organization of the United Nations. http://www.fao.org/3/I8329EN/ i8329en.pdf

Wang, S., Tang, X., Wang, L., Zhang, Y., Wu, Q., \& Xie, W. (2014). Effects of sublethal concentrations of bifenthrin on the two-spotted spider mite, Tetranychus urticae (Acari: Tetranychidae). Systematic and Applied Acarology, 19(4), 481490. https://doi.org/10.11158/saa.19.4.11 
Silas Wintuma Avicor, Richard Adu-Acheampong and Godfred Kweku Awudzi

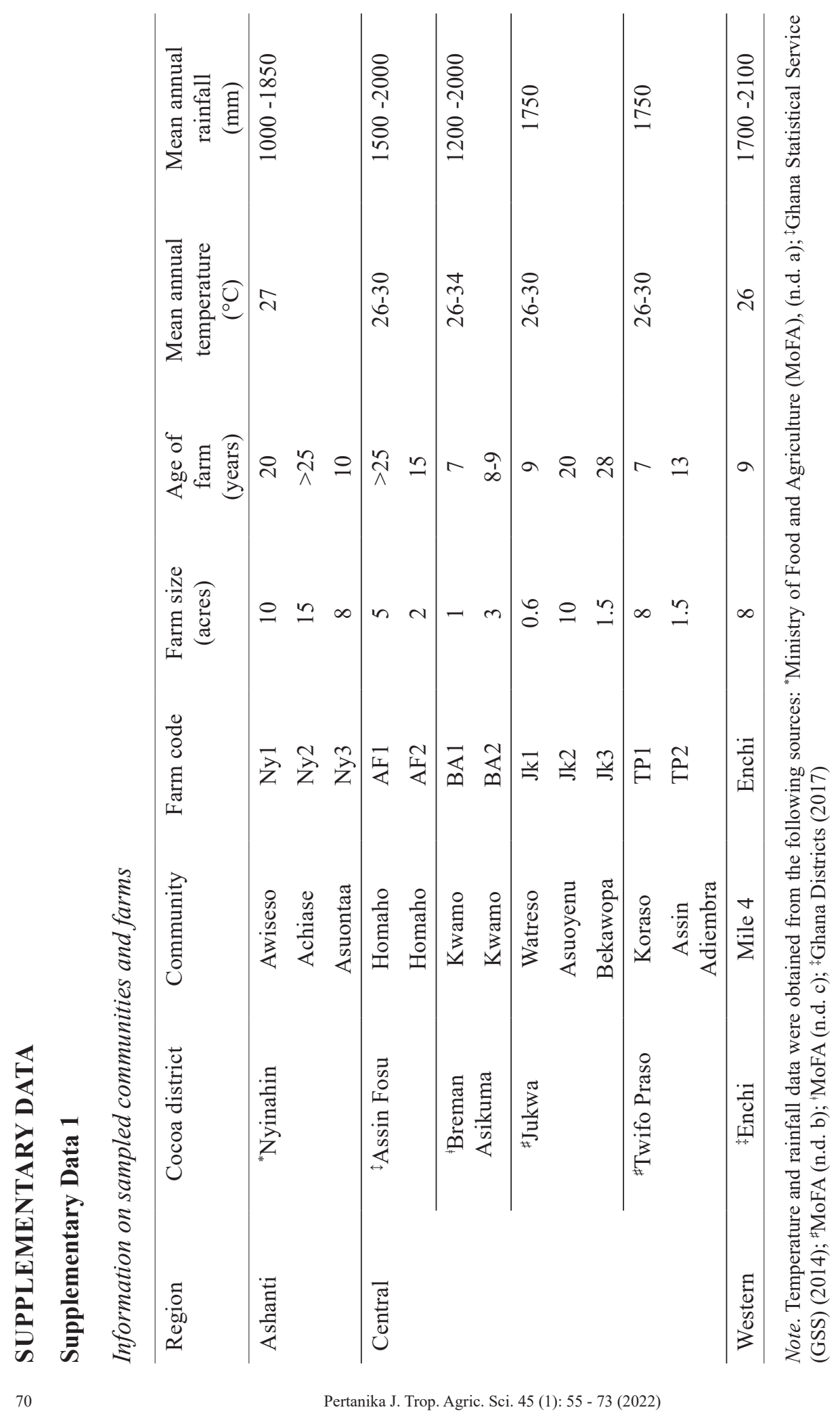




\section{Supplementary Data 2}

Insect damage, pest, and part of plant affected

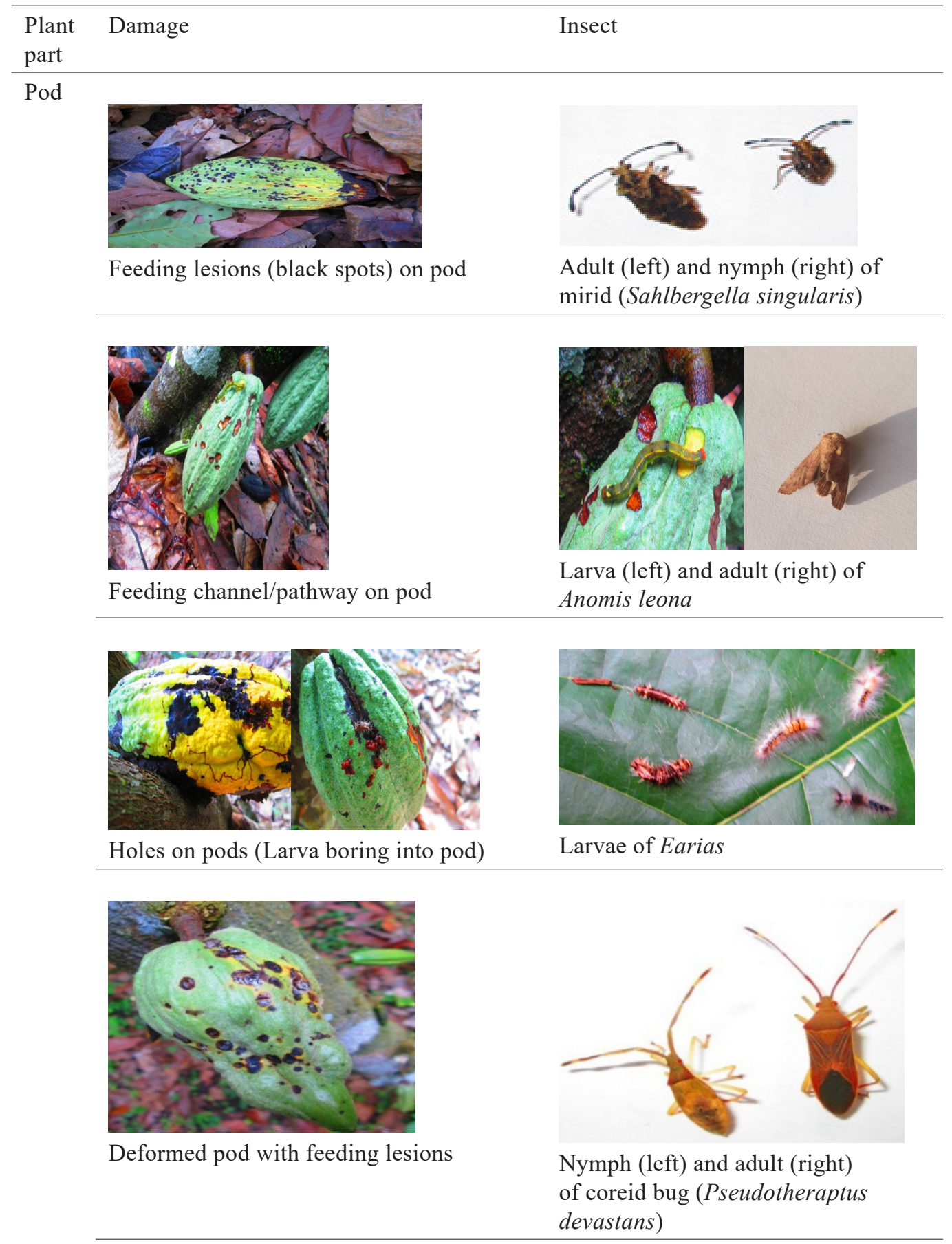




\section{Supplentary Data 2 (Continue)}

\begin{tabular}{|c|c|c|}
\hline $\begin{array}{l}\text { Plant } \\
\text { part }\end{array}$ & Damage & Insect \\
\hline Pod & 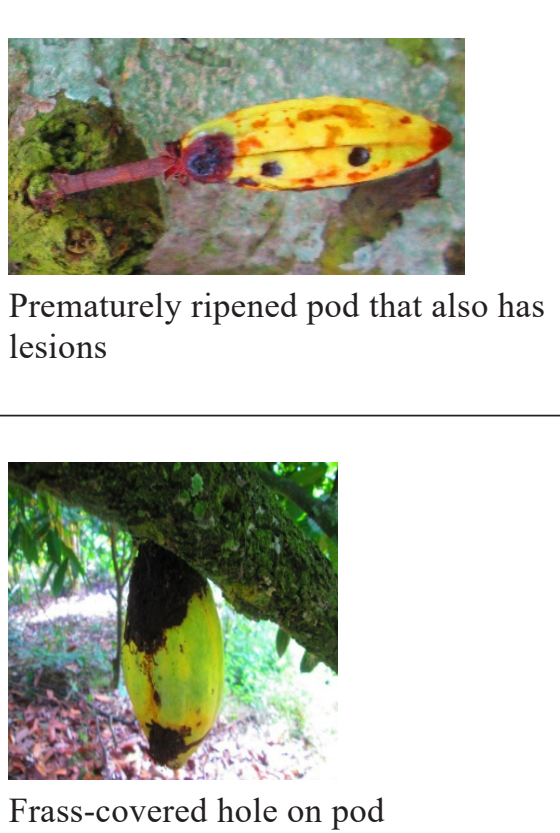 & $\begin{array}{l}\text { Adult (left) and nymph (right) of stink } \\
\text { bug (Bathycoelia thalassina) }\end{array}$ \\
\hline
\end{tabular}

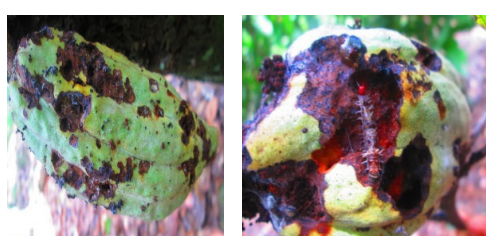

Co-infestation of pods by larvae of Anomis and Earias

Holes/feeding cavities/pathways on pods

Stem
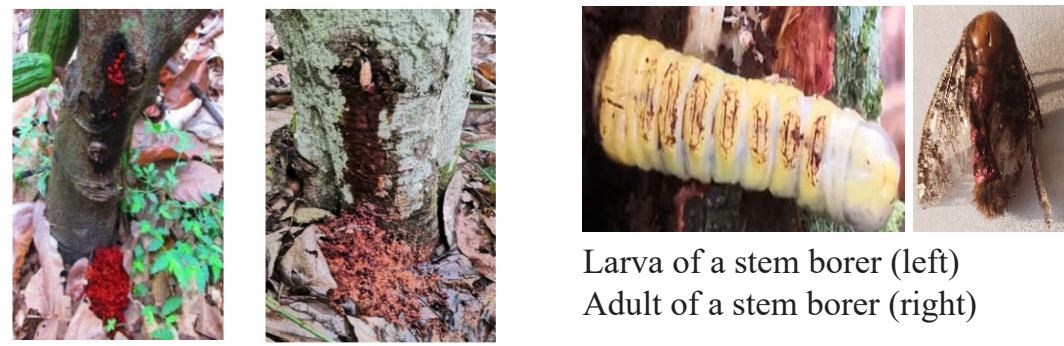

Larva of a stem borer (left)

Adult of a stem borer (right)

Hole in trees with frass at entrance of hole and base of trees 
Supplentary Data 2 (Continue)

\begin{tabular}{lll}
\hline $\begin{array}{l}\text { Plant } \\
\text { part }\end{array}$ & Damage & Insect \\
\hline Leaf & $\begin{array}{l}\text { Defoliators including larvae of } \\
\text { Anomis and Earias }\end{array}$ \\
& \\
&
\end{tabular}


